\title{
ADAPTIVE FINANCING PATTERN FOR SMALL SCALE FISHERIES WITH CASE STUDY OF PAJEKO FISHERIES IN BITUNG
}

\author{
Fini Lovita*), Arif Satria**), and Dedi Budiman Hakim ${ }^{* * *}$ \\ *) School of Business, IPB University \\ Jl. Pajajaran, Bogor 16151, Indonesia \\ **) Department of Communication and Community Development, Faculty of Human Ecology, IPB University \\ Jl. Kamper, Campus of IPB Darmaga Bogor 16680, Indonesia \\ ${ }^{* * *}$ Department of Economics, Faculty of Economics and Management, IPB University \\ Jl. Agatis, Campus of IPB Darmaga Bogor 16680, Indonesia
}

\begin{abstract}
The agriculture, forestry, and fisheries sectors have a share of $22.05 \%$ with $4.21 \%$ growth in North Sulawesi. The fisheries sub-sector dominates by $30 \%$. The disbursement of banking institutions' credit for the sector increased by 35\% in 2015-2017 but absorbs only $7 \%$ of total loans disbursed. The reluctance of formal financial institutions to provide credit to improve small fisheries has increased in non-formal financing. This study identifies factors influencing financing sources choice, comparison of bank and non-bank financing sources, and recommend adaptive financing patterns for small fisheries. Based on descriptive qualitative analysis of in-depth interviews with 32 respondents from 85 Pajeko fishers (mini purse seine) in the Bitung Oceanic Fishing Port (PPS), concluded that $97 \%$ of Pajeko fishers in Bitung chose non-bank to finance their operation with determinant factors of financial source: (i) easiness administration (88\%), (ii) payment flexibility (78\%), and (iii) collateral $(69 \%)$. The result of comparison simulation shows that boat owner financing with profit sharing for three (boat, boat owner, crews) is the most profitable for the boat owner, while bank loan financing with profit sharing for two (boat owner, crews) is the most profitable for crews. Accordingly, an adaptive financing strategy development is recommended for banking institutions based on influencing factors of fisher's choices and Pajeko fisher's characteristics-based approach.
\end{abstract}

Keywords: Pajeko fishery, resource of financing, bank financing source, non-bank financing source, adaptive financing

\begin{abstract}
Abstrak: Sektor pertanian, kehutanan, dan perikanan memiliki pangsa 22,05\% dan pertumbuhan 4,21\% di Sulawesi Utara. Sub-sektor perikanan mendominasi sebesar 30\%. Penyaluran kredit lembaga perbankan untuk sektor tersebut meningkat 35\% pada 20152017, namun hanya menyerap 7\% dari total kredit yang disalurkan. Keengganan lembaga keuangan formal menyalurkan kredit untuk pengembangan usaha perikanan tangkap mendorong peningkatan pembiayaan non-formal. Penelitian ini mengidentifikasi faktorfaktor yang memengaruhi pilihan nelayan kecil atas sumber pembiayaan, membandingkan pembiayaan bank dan non-bank, serta merekomendasikan pola pembiayaan adaptif bagi nelayan kecil. Berdasarkan analisa deskriptif kualitatif hasil wawancara mendalam dengan 32 responden dari 85 nelayan pajeko (mini purse seine) di Pelabuhan Perikanan Samudera (PPS) Bitung, disimpulkan bahwa 97\% nelayan pajeko di Bitung memilih pembiayaan nonbank untuk operasional dengan faktor penentu pemilihan sumber pembiayaan adalah: (i) kemudahaan administrasi (88\%), (ii) fleksibilitas pembayaran (78\%), dan (iii) jaminan (69\%). Hasil simulasi menunjukkan sumber pembiayaan dari pemilik kapal dengan pendapatan bersih dibagi tiga (kapal, pemilik kapal, kru kapal) paling menguntungkan bagi pemilik kapal, sementara pembiayaan dari bank dengan pendapatan bersih dibagi dua (pemilik kapal, kru kapal) paling menguntungkan bagi kru kapal. Untuk itu, disarankan agar lembaga perbankan menyiapkan strategi pembiayaan adaptif berdasarkan faktorfaktor yang memengaruhi pilihan nelayan dan melakukan pendekatan sesuai karakteristik nelayan pajeko.
\end{abstract}

Kata kunci: perikanan pajeko, sumber pembiayaan, sumber pembiayaan bank, sumber pembiayaan non-bank, pembiayaan adaptif

${ }^{1}$ Corresponding author:

Email: fini.lovita@gmail.com 


\section{INTRODUCTION}

Fisheries is an important economic sector and a major contributor to the growth development of the province of North Sulawesi. According to Nugrohadi (2013), the fisheries and marine sector have the opportunity to be developed into leading sectors in international trade. Support for this sector is very important in accelerating regional development. As also conveyed by the Governor of North Sulawesi Province at the North Sulawesi marine and fisheries development technical meeting in April 2019, that the marine and fisheries sector is one of the regional development priority programs, in order to actualize food sovereignty in supporting various other development sectors (www. manado.tribunnews .com).

The production of the marine and fisheries sector in North Sulawesi tends to increase every year. After the decline in production in 2015, this sector has increased again starting in 2016, especially for small pelagic capture fisheries. Small pelagic fisheries are generally operated using a small purse seine on a machine boat of less than 20 Gross Tonnage (GT) or commonly referred to as a pajeko boat. Ilhamdi (2013) states that based on the catch target, the purse seine is divided into two, the purse seine with large pelagic fish target and the purse seine with the small pelagic fish target.

Mini purse seine fishing (also called soma pajeko) is an economic activity that has long been carried out by fishermen using very limited personal capital (Hajatuddin, 2008). Up until now, this activity recognized as one of the prime movers' sectors in the fisheries because it provides a large contribution compared to aquaculture. This capture fishery in general still uses simple technology with a limited operating range so that its productivity is relatively low.

Based on the North Sulawesi Province Capture Fisheries Statistics Data in 2016, pajekos operating in the region are 1,746 or around $26 \%$ of the total motorboats registered in North Sulawesi. Pajeko production is volatile and very much depends on weather conditions and business capacity. Hidayat (2009) examined, among others, the productivity of small-scale capture fisheries and concluded that the intensity of fishing units is influenced by the season so that its production fluctuates throughout the year. Fluctuating pajeko production results in a low level of certainty of pajeko income. This causes slow business growth.
Pajeko fisheries require capital support from outside parties, including financial institutions, for business improvement. Lewar (2017) states that the production of traditional fishermen is influenced positively and significantly by capital variables. While according to Kusumawati (2010), small-scale capture fisheries businesses need support to be able to access credit with low-interest rates to help with capital. This support will help improve the performance of small-scale fisheries. Indonesian capture fisheries are dominated by smallscale fisheries where the business patterns influenced by environmental conditions, capital capabilities, and fishermen's skills (Fathanah, 2014). Considered as small-scale fisheries, Pajeko is categorized as micro, small, and medium (MSM) businesses. MSM businesses need training and access to capital in order to maximize business development (Respatiningsih, 2011). Suci (2017) and Wijaya (2010) confirmed that in order to improve their business capabilities, MSM needs capital support, in terms of numbers and sources.

Considering that the capture fisheries sector in North Sulawesi is an important economic sector and is one of the main contributors to development growth, this sector has a potential market for banking institutions. This is in line with one of the main functions of the banking sector in channeling funds to the public through the provision of financial assistance for MSM businesses that need support to develop and strengthen their businesses (Destiana, 2016). According to Panekenan (2017), banks in North Sulawesi have great potential in financing the agricultural sector. However, banking institutions are advised to be more proactive in directing prospective borrowers in meeting the requirements of credit financing service procedures (Karauwan, 2012). Based on the report of the Department of Development of MSM Businesses of Bank of Indonesia (2016), fisheries financing must be adjusted to the characteristics of coastal communities and unbankable communities, the majority of which are included in the micro and small business groups. Therefore, banking institutions can offer financing schemes with relief in requirements in the form of grace period system according to the season, as well as restructuring installments during the low season. Fishermen can continue to pay credit installments after the low season.

However, in reality, small-scale fisheries have financial barriers with limited access to credit to formal financial institutions. Abdesamad (2014) states that banking institutions in most developing countries are often 
unable or unwilling to provide loans to small and medium-sized businesses that have difficulty providing collateral as one of the requirements for applying for bank loans. Bank of Indonesia itself stated on its official website (https://www.bi.go.id/id/umkm/ kelariah/pola-pembinance/default.aspx) that there are still many small-scale business operators who have difficulty getting access to banks credit, both due to technical constraints, such as insufficient collateral, and non-technical constraints, such as limited access to banking information. Various obstacles to financial access for MSM businesses in developing their businesses are due to the lack of information related to the formal financing sector, high transaction costs, and complicated financing procedures (Jasuni, 2018). According to Purba (2008), some financial institutions do not have a significant role in building small-scale fisheries, among others, due to inappropriate credit scaling, relationships that are not well-built, and the establishment of guarantees that cannot be met by small-scale fisheries. In more detail, Nababan (2013) sees that the factors that influence the community's decision to choose a financial institution as a source of funding are the interest rate, the administration of credit management, the collateral determined, and the credibility of banks in the community.

Limited access to small-scale fisheries financing encourages fishers to look for non-bank financing alternatives. As stated by Masyhuri (2014), that for most small fishermen in Bitung, investment capital is an obstacle in fisheries development. The reluctance of formal financial institutions to extend credit for fisheries development has encouraged high financing from the informal or non-bank sectors. According to Nurlestari (2015), in general, MSM business capital can be obtained from two sources, internal financing from very limited own capital (non-bank) and external financing from financial institution credit loans (bank). Limited access to small-scale fisheries financing encourages fishers to look for non-bank financing alternatives. As stated by Masyhuri (2014), that for most small fishermen in Bitung, investment capital is an obstacle in fisheries development. The reluctance of formal financial institutions to extend credit for fisheries development has encouraged high financing from the informal or non-bank sectors. According to Nurlestari (2015), in general, MSM business capital can be obtained from two sources, internal financing from very limited own capital (non-bank) and external financing from financial institution credit loans (bank). This study analyzes the factors that influence Pajeko fisheries in determining the choice of financing sources, both from banks or non-banks. This study also provides recommendations for banking institutions on the financing programs for small-scale fisheries based on the characteristics of Pajeko fisheries in Bitung. So that it is expected to have implications for the management of banking institutions in improving understanding of small-scale fisheries and preparing adaptive strategies. This study limits the scope of respondents from capture fisheries, especially pajeko-type vessels with a capacity of less than 20 GT. The pajeko studied are those that use mini purse-seine fishing gear and the main targeted species of Layang/Malalugis (Scad). Meanwhile, the non-bank funding sources referred to in this study are individual creditors in Bitung. Limited access to small-scale fisheries financing encourages fishers to look for non-bank financing alternatives. As stated by Masyhuri (2014), that for most small fishermen in Bitung, investment capital is an obstacle in fisheries development. The reluctance of formal financial institutions to extend credit for fisheries development has encouraged high financing from the informal or non-bank sectors. According to Nurlestari (2015), in general, MSM business capital can be obtained from two sources, internal financing from very limited own capital (non-bank) and external financing from financial institution credit loans (bank).

In order to capture the small-scale fisheries market share, banking institutions need to innovate more through business financing programs that are adaptive to industrial capacity. A similar statement was delivered by Yuniarti (2010) in her research on the Rural Bank (BPR) strategy. Yuniarti saw that in order to win the competition of financial institutions in capturing the market share of the small business financing sector, BPR created an adaptive strategy. These strategies include strengthening industrial infrastructure, partnership programs with commercial banks, and maintaining flexibility in working with the lower middle economic community. Adaptive strategies are solutions that promote flexibility, the ability to respond to changes, and adapt as needed. In a study related to the adaptive behavior of forest edge farmers, Santoso (2010) explained that what is meant by adaptive behavior is behavior-oriented towards meeting the needs of conducting economic activities both in agriculture and non-agriculture. 
This study analyzes the factors that influence Pajeko fisheries in determining the choice of financing sources, both from banks or non-banks. This study also provides recommendations for banking institutions on the financing programs for small-scale fisheries based on the characteristics of Pajeko fisheries in Bitung. So that it is expected to have implications for the management of banking institutions in improving understanding of small-scale fisheries and preparing adaptive strategies. This study limits the scope of respondents from capture fisheries, especially pajeko-type vessels with a capacity of less than 20 GT. The pajeko studied are those that use mini purse-seine fishing gear and the main targeted species of Layang/Malalugis (Scad). Meanwhile, the non-bank funding sources referred to in this study are individual creditors in Bitung.

\section{METHODS}

The study was conducted at the Bitung Oceanic Fishing Port (PPS), North Sulawesi. The determination of the sample is done through a purposive sampling method where the target is a pajeko boat fisherman with a capacity of $<20$ GT and uses mini purse seine fishing gear. The purposive sampling method is used to obtain more specific data of pajeko fisheries considering there are many types of small-scale fisheries in Bitung.

Primary data were obtained through in-depth interviews with 32 respondents or around $38 \%$ of the 85 pajeko vessels registered in PPS Bitung. Data collection conducted in September 2017 and completed in October 2018. Interviews were conducted using a questionnaire method with a list of open-ended questions to the owner and captain. The questionnaire consisted of 6 sets of questions related to respondent information, business capacity, season cycles, catches during interviews, preference for financing patterns, and data record management.

Secondary data was obtained through the collection of statistical data on capture fisheries in 2012-2017 from PPS Bitung. Secondary data also comes from downloading statistical data from the internet during the study period. Furthermore, secondary data is reprocessed according to research needs to explain conditions of capture fisheries in PPS Bitung and set forth in tables and diagrams.
Both primary and secondary data are then analyzed using qualitative descriptive methods. Descriptive analysis is intended to explore and clarify the characteristics of pajeko fisheries and provide a further description of the factors that influence the selection of financing sources for pajeko fishing in Bitung. This qualitative descriptive study does not draw relationships between the factors that exist and does not attempt to generalize to the influence of each factor. Therefore, this research did not do hypothesis testing.

Both primary and secondary data are then analyzed using qualitative descriptive methods. Descriptive analysis is intended to explore and clarify the characteristics of pajeko fisheries and provide a further description of the factors that influence the selection of financing sources for pajeko fishing in Bitung. This qualitative descriptive study does not draw relationships between the factors that exist and does not attempt to generalize to the influence of each factor. Therefore, this research did not do hypothesis testing.

The three financing schemes are combined with the two net revenue sharing schemes. The combined scheme results in 6 schemes for comparison. These schemes are: 1) financing from boat owner with three revenue sharing, 2) financing from boat owner with two revenue sharing, 3) financing from other boat owners with three revenue sharing, 4) financing from other boat owners with two revenue sharing, 5) financing from Bank BRI with three revenue sharing, and 6) financing from Bank BRI with two revenue sharing.

Based on previous studies, this study concludes that the influencing factors of the selection of financing sources for small-scale fisheries are 1) access and process, 2) interest, 3) collateral, 4) installment mechanism, and 5) loan term. These five factors influence the choice of financing sources for pajeko fisheries with an expectation of the right choice to be able to finance the pajeko fisheries in an adaptive manner. Based on the background and problems observed, the relationship of these factors can be described as a conceptual framework can be briefly seen in Figure 1 .

The above conceptual framework can explain that there are five factors that influence pajeko fisheries in determining the choice of business financing sources. The five factors are analyzed descriptively to explain in detail the effect of each of them on the choice of fishermen. Next is a simulation of pajeko's income using 
a bank and non-bank financing scheme, to see the most profitable financing scheme. Based on the descriptive analysis and simulation, pajeko fisheries can determine the most profitable and adaptive financing sources for their business capacity.

\section{RESULTS}

\section{Capture fisheries in Bitung}

As one of the gates in and out of fishery commodities in eastern Indonesia, Bitung has a PPS which is very strategically located. Witomo (2012) in his research stated that the main commodities of capture fisheries in Bitung were Tuna (Thunnus spp.), Skipjack (Katsuwonus pelamis) and Layang (Decapterus spp.). The three main commodities of fisheries come from local fishers using purse seine, handline and pole and line (huhate) fishing gears. Based on the production data of Layang fisheries in Bitung, the following graphs of the volume and selling price show the catch and landing at Bitung PPS in the 2012-2017 period can be seen in Figure 2.

The production volume diagram above shows the difference between the highest and the lowest peak production in one year with an average of more than 350,000 tons. The year of 2014 was the highest difference between top and lowest of the curve of about 800,000 tons. However, the highest production peak occurred in 2015 with production of more than 1 million tons. The production has a tendency to decrease when entering the end of 2015 to the lowest point in the first quarter of 2016. The increase in production in the remaining quarter of 2016 is not too significant with the difference in production at the highest peak with the lowest peak of less than 400,000 tons.

Figure 3 shows very volatile selling prices of Layang at PPS Bitung. The downward trend of prices is quite long, starting from the end of 2013 and reaching a turning point in early 2015. Starting in 2015, fish prices have tended to increase. The price of fish had experienced the highest price in the past six years amounting to Rp18,688 in July 2017. Overall, the price of Layang at PPS Bitung experienced quite sharp fluctuations in the period 2012-2017.

\section{Regional Economy}

The report on the economic conditions of the North Sulawesi region shows the potential of a capture fisheries credit financing program in Bitung. On the one hand, the potential has an appeal for banks. But on the other hand, this potential leaves high vigilance against the high potential for Non-Performing Loan (NPL).

The average NPL ratio per year from the agriculture, forestry, and fisheries sectors in North Sulawesi province is more than $5 \%$. The tendency to increase the NPL ratio began in 2012 to 2016 . Where the highest NPL ratio occurred in 2015 with a ratio of $9.94 \%$. This figure far exceeds the maximum limit of banking NPL set by the Financial Services Authority (OJK).

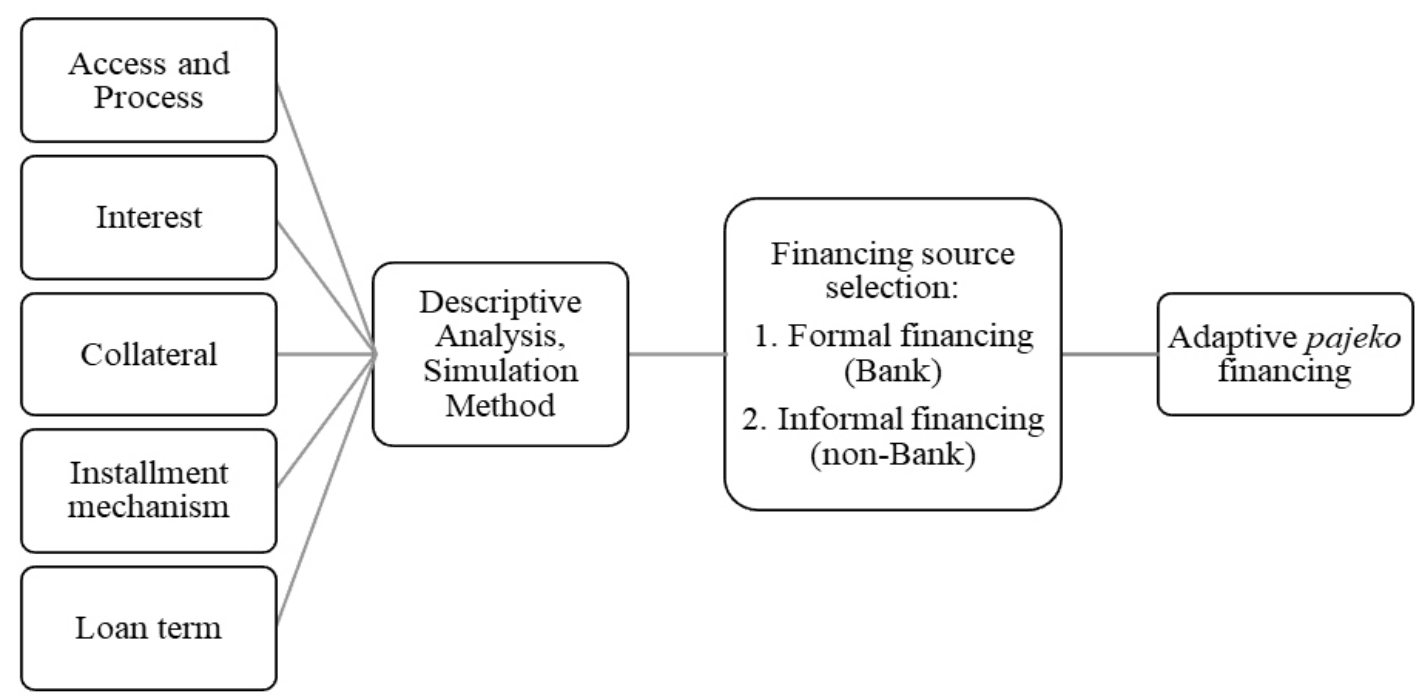

Figure 1. Conceptual framework 


\section{$1,200,000$}

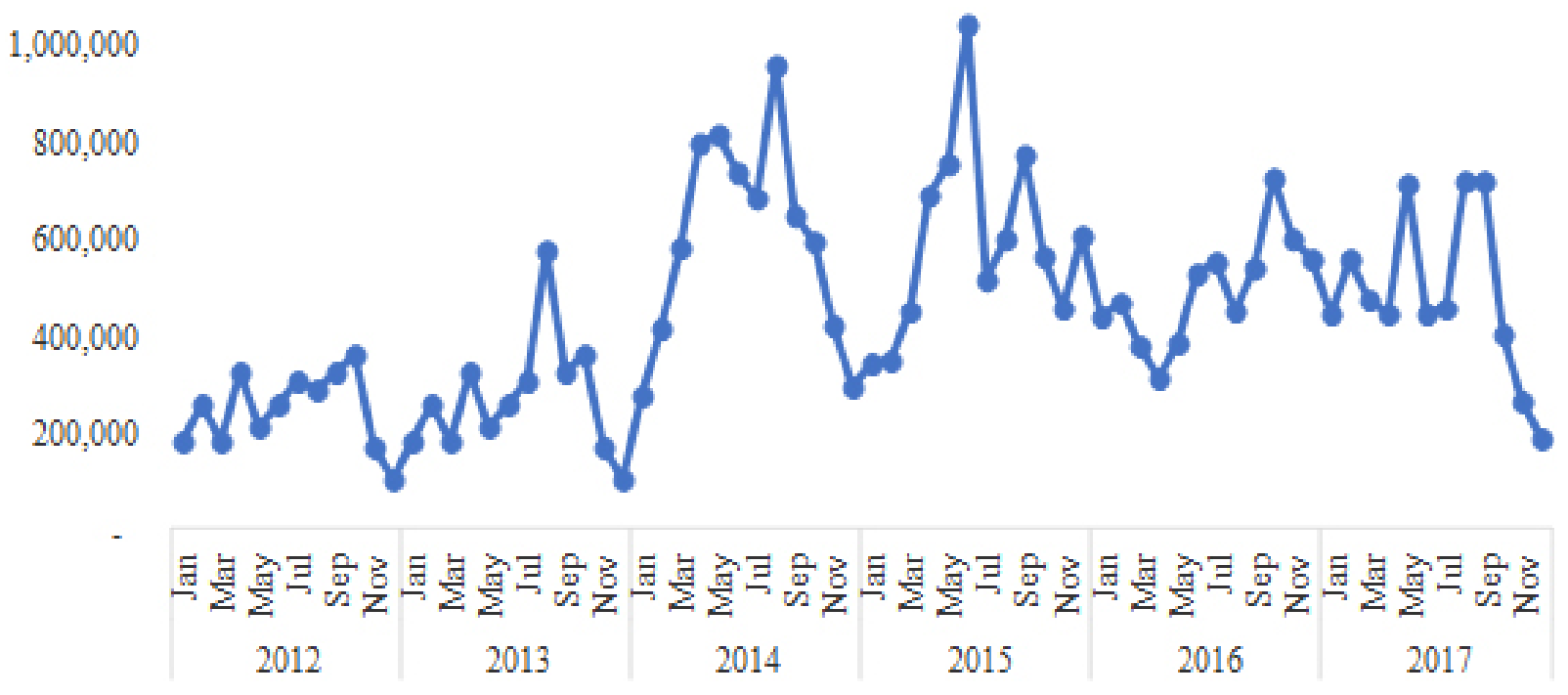

Figure 2. Volume of fisheries production of layang/malalugis (Scad Sp.) at PPS Bitung (Oceanic Fishing Port of Bitung, 2017)

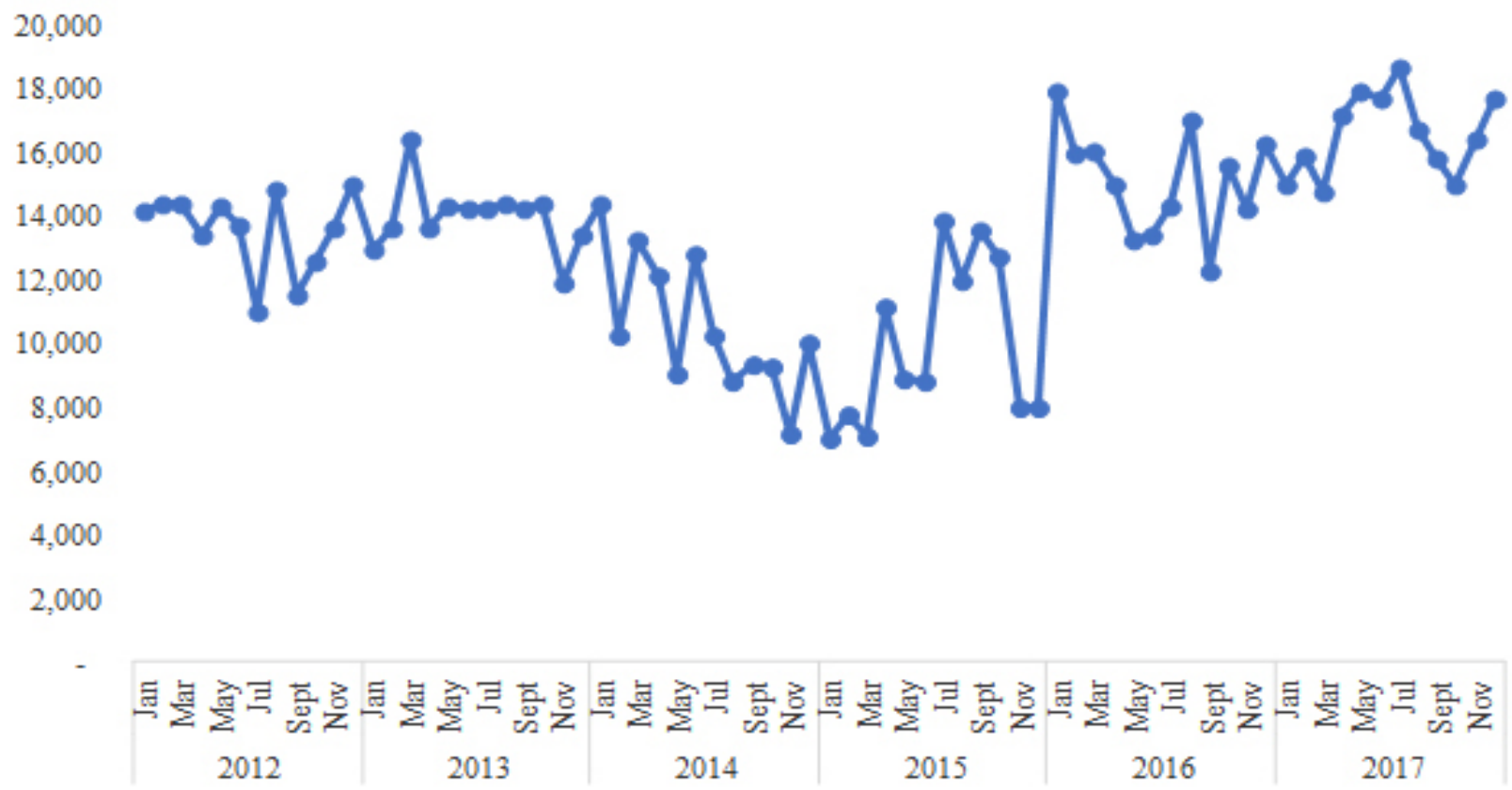

Figure 3. Selling price of layang/malalugis (Scad Sp.) at PPS Bitung (Oceanic Fishing Port of Bitung, 2017)

As the center of the capture fisheries industry in eastern Indonesia, Bitung is the largest contributor to fish production in North Sulawesi Province. But in the period of 2012-2016, Bitung recorded a significant decline in fisheries production. The fisheries report of North Sulawesi Province Marine Affairs and Fisheries Office (DKP) in 2012-2016 shows the fisheries production of Bitung and the percentage of the total production of North Sulawesi Province. Production report can be seen in Table 1.
The above table shows a significant decrease in fish production in Bitung in 2015 by $65 \%$. Production in 2016 experienced a correction of $13.5 \%$. However, this figure is still much smaller compared to production in previous years. The decline in Bitung fisheries production is closely correlated with an increase in the NPL ratio of North Sulawesi Province banking institutions which peaked in 2015. Therefore, it is expected that the reluctance of banking institutions in financial channeling for capture fisheries in North Sulawesi is due to their concern on the potential NPL. 
Table 1. The fisheries production of Bitung and the percentage of the total production of North Sulawesi Province

\begin{tabular}{lccccc}
\hline & 2012 & 2013 & 2014 & 2015 & 2016 \\
\hline Bitung & $159,318.00$ & $134,247.30$ & $142,626.90$ & $49,483.70$ & $56,167.40$ \\
Other Cities/Regencies & $120,004.90$ & $215,073.70$ & $152,576.50$ & $235,781.90$ & $246,630.90$ \\
Total & $279,322.90$ & $349,321.00$ & $295,203.40$ & $285,265.60$ & $302,798.30$ \\
Bitung of Total (\%) & $57.04 \%$ & $38.43 \%$ & $48.31 \%$ & $17.35 \%$ & $18.55 \%$ \\
\hline
\end{tabular}

Source: Production Report of Marine Affairs and Fisheries Office North Sulawesi, 2012-2016

\section{Research Respondents}

Respondents in this study are $75 \%$ of were originally from Bitung, followed with $16 \%$ of respondents from Sangihe Islands. The remainder comes from other districts in North Sulawesi. The population of Bitung is mostly from the Minahasa and Sangir ethnic groups. The Sangir ethnicity is an ethnic group originating from the Sangihe-Talaud Islands, located north of North Sulawesi. The Sangir community is famous for its expertise as a fisherman.

The majority of respondents are in the age group of $40-49$ years, which is $75 \%$, followed by the age group of 50-59 years. Meanwhile, respondents with a junior high school education are $47 \%$. The second latest educational background is elementary school with $28 \%$. Respondents with Senior High School background are $16 \%$. According to this fact, it can be concluded that in general boat owners and captains are those of mature age with lower secondary education. The expertise they have is gained from decades of work experience.

\section{Average Production and Earnings}

Based on the results of the interviews, significant differences shown in average production during peak, moderate and low seasons. Changes in the volume of the average catch is inversely proportional to changes in the average selling price at the Fish Auction Place (TPI) of PPS Bitung with a range of average prices in the peak and low seasons between Rp14,888 - Rp17,799 per kg. During peak season, the average income can reach at $\mathrm{Rp} 1,399,472,000$ per month. These conditions significantly decreased during the low season.

The significance of the difference in production and income of pajeko fisheries in Bitung in each season increases the caution of the banks in extending credit loan. The potential for installment payment failures is huge, especially in the low season for several months each year. This makes it more difficult for pajeko businesses in order to improve their business.

\section{Source of Business Financing and Bank Account Ownership}

Respondents have a preference in determining the source of financing to support their increased productivity. The preference is divided into two choices, bank, and nonbank financing sources. The following Table 2 shows the respondents' choice of financial sources, both for the purchase and/or improvement of working assets and for fishing operations.

Table 2. Respondents' choice for financing need

\begin{tabular}{lcccc}
\hline \multirow{2}{*}{ Financing need } & \multicolumn{2}{c}{ Bank } & \multicolumn{3}{c}{ Non-Bank } \\
\cline { 2 - 5 } & \#Respondent & $\%$ & \#Respondent & $\%$ \\
\hline $\begin{array}{l}\text { Asset (boat, } \\
\text { fishing gear, etc.) }\end{array}$ & 5 & 16 & 27 & 84 \\
$\begin{array}{l}\text { Operation (bait, } \\
\text { ice, etc.) }\end{array}$ & 1 & 3 & 31 & 97 \\
\hline
\end{tabular}

Regarding sources of financing for the purchase or improvement of assets that have so far been used, $84 \%$ of respondents prefer to have non-bank financing sources. Specifically, respondents mentioned the preference of loans to individuals they knew well. Likewise, sources of financing for business operations, $97 \%$ of respondents chose non-bank financing sources.

The data shows that the majority of respondents chose non-bank financing sources. There is one respondent who chooses a bank as a source of business financing. Based on in-depth interviews with the respondent, it was explained that this was because the respondent felt comfortable with the facilities offered by the bank that he ever obtained.

On the other hand, $69 \%$ of respondents are bank customers in Bitung. Some respondents even have accounts in several banks. However, almost all of these 
accounts are not under the respondent' name, but in the names of their wives and children. This shows that almost all respondents have interacted with banking institutions through savings account ownership, but only one respondent used a bank financing program. Therefore, it can be concluded that pajeko fishermen are reluctant to take advantage of the financing programs offered by banks, even though at the same time they are utilizing bank savings programs. From further interviews, respondents explained that the reluctance was due to the lack of information they had regarding the bank's financing program.

\section{Banking Perception of Pajeko Fisheries in Bitung}

North Sulawesi has 49 banks in 2017 consisting of commercial banks, rural banks, and Islamic banks serving various financial needs of the community. The banks are spread throughout the province. Bank BRI is one of the banks with branch offices widely spread to remote districts in North Sulawesi Province. One of BRI's branch offices is located in Bitung with main target customers include capture fisheries.

Bank BRI branch of Bitung stipulates that one of the requirements for applying for a Community's Business Credit (KUR) loan is the binding of collateral worth at least $100 \%$ of the loan. The recognized collateral in the form of fixed assets consists of land, buildings, other immovable objects, and other movable objects that are equivalent - gold, bonds, sukuk, and others. Meanwhile, collateral in the form of a less than $10 \mathrm{GT}$ fishing boat requires a gross deed or ship measurement letter from the local Transportation Office. Bank BRI also provides a restructuring policy for loans that are declared non-performing (non-Performing Loans). The restructuring will take place in the middle of the loan period in the form of 1) extension of the loan period, 2) interest relief between 1-5\%, and 3) write-off of past installments.

Based on a further open interview with the management of Bank BRI Bitung, in 2015-2017 there was an increase in NPL from fisheries sector customers as a result of the decrease in the availability of raw materials for production in the fish processing industry in Bitung. This condition resulted in many BRI Bank customers unable to pay their credit installments on time. As an anticipatory measure, in addition to offering credit restructuring, bank management tightened the screening process for credit proposals in the following years.

\section{Factors that Influence the Selection of Financing Sources}

To understand respondents' opinions about the factors that influence the selection of financing sources, the following is an explanation based on the results of interviews with 32 respondents. The results of the interview show the priority of influencing factors based on the number of voted respondents. The more respondents choose a factor, the factor is considered the most priority. Conversely, the fewer respondents who choose a factor, the factor is considered the lowest priority.

Respondents' choice of factors influencing: 1) Access and process factors $(88 \%$ of respondents choose to access and process as the factor that most influences their choice of financing sources. In general, respondents want access to finance with a service process that is fast, easy, and delivered in a language that is easily understood. Complicated administrative processes with various requirements are not only confusing but also reduce fishermen's interest to apply for a loan); 2) Installment payment factor (Furthermore, $78 \%$ of respondents chose the installment mechanism as the factor that most influenced them in choosing the source of financing. The majority of fishermen are worried about their inability to repay loans on time. Especially during the low season. Therefore, the flat payment system per month is considered uneasy by fishermen); 3) Collateral factor (As many as $69 \%$ of respondents chose collateral as a factor influencing their choice of financing sources to improve their business. That is because the majority of fishermen do not have assets that can be used as collateral as required. Only a few fishermen own houses with certificates in their names. So that the requirements for applying for credit by providing collateral often close the access of pajeko fishermen to the bank financing program); 4) Interest factor $(59 \%$ of respondents chose the loan interest rate as an important consideration in deciding whether they would use a financing program from a banking institution or preferably use a non-bank financing program. However, around $41 \%$ of respondents said they did not really question the amount of the specified loan interest. Those who fall into this category assume that the determination of bank loan interest is quite reasonable); 5) Loan term factor ( $66 \%$ of respondents stated that the loan period is not a factor that significantly influences the choice of financing for pajeko businesses. In general, pajeko fishermen assume 
that the loan period is a flexible policy. So that at any time it can be negotiated with creditors).

\section{Bank and Non-bank Business Financing}

The following Table 3, compares the sources of bank and non-bank financing based on factors that influence their selection. The table is a summary of the various opinions of the majority of respondents on each factor. Respondents' opinions are based on their experience and knowledge at the time of the interview. From the Table 3, a brief comparison can be explained by respondents with the two sources of financing, bank, and non-bank, as follows:

1. Access and process factors.

Ease of access and speed of the loan application process until funds are sent to the debtor are the main advantages of non-bank financing sources. The standard operating procedures applied are simple. Decision making is generally carried out by one person, the owner. So that the entire credit process can be carried out in a short time. Sometimes even less than 24 hours. On the other hand, credit services and administration at banking institutions are carried out according to standard operating procedures with stages that should not be missed. Decision making at each of these stages has its own legality. Overall, the series of applications for credit approval takes quite a long time. It takes days to weeks to get the loan approval only.

2. Installment payment factor.

Non-bank financing sources, especially from individuals, are more flexible in determining the mechanism for repaying credit installments. In certain conditions, it can be adjusted according to requests and agreements with the debtor. For example, in a low season, creditors provide relief by transferring installments on the following season or charging interest on loans the following season. In banking institutions, the credit restructuring policy for the category of bad loans can be done based on the request of the debtor in good faith to repay the loan. However, this policy cannot necessarily be carried out. The decision to grant the restructuring was based on several considerations from the branch leading to the bank's regional leadership.

3. Collateral factor.

Collateral is one of the main conditions that must be prepared by the debtor. Collateral types and values are determined through head office policy. Branch offices do not have flexibility in determining collateral types and values. When bad credit occurs, the collateral will be confiscated by the bank. On the contrary, non-bank financing sources, especially non-bank individuals, do not establish collateral as a condition for loans to pajeko fishermen. In general, a debtor is a person who is well known by the creditor. Some pajeko fishermen even have a kinship with creditors. So that the loan process is based on trust. This facilitates access for pajeko fishermen to business financing sources.

4. Interest factor.

According to the interest rates, respondents see no difference between banks and non-banks. Even though for non-banks, they usually do not refer to as interest but creditors' income or profits. Respondents assume that the interest or profit-sharing determined by the creditor is reasonable and can be accepted as reasonable.

5. Loan term factor.

Respondents assume that both banks and non-banks offer sufficient loan terms. In general, the stipulated period ranges from 1-2 years. For pajeko fisheries, this period is considered sufficient.

Table 3. Compares the sources of bank and non-bank financing based on factors that influence their selection

\begin{tabular}{|c|c|c|}
\hline \multirow{2}{*}{ Affecting factors } & \multicolumn{2}{|c|}{ Financing sources comparison } \\
\hline & Bank & Non-Bank \\
\hline Access and process & Slow and complicated & Fast and easy \\
\hline Installment payment & According to the procedure and not flexible & Flexible and negotiable at any time \\
\hline Collateral & One of credit requirement & Not credit requirement \\
\hline Interest & Reasonable and acceptable & $\begin{array}{l}\text { Reasonable and acceptable (usually called } \\
\text { profit sharing) }\end{array}$ \\
\hline Loan term & Appropriate & Appropriate \\
\hline
\end{tabular}


6. It's just that some input from respondents regarding the constraint during catch season is the flexibility of credit restructuring through changes in the loan term. In bank financing, restructuring is only given after a bad credit occurs. The procedure for filing a restructuring process takes time. While for nonbanks, restructuring can be given immediately when the low season starts.

\section{Bank and Non-bank Financing Scheme Simulations with the Distribution of Operation Earning}

Pajeko fishermen in Bitung tend to choose individual non-bank financing sources to increase production. For this reason, the research tries to simulate bank and non-bank financing schemes by dividing the business revenue to see the scheme that benefits the parties, ship owners, and crew best. This study uses several assumptions, including: a) utilization of the KUR program of Bank BRI with an interest rate of $9 \%$ and a monthly administration fee of $\mathrm{Rp} 50,000, \mathrm{~b}$ ) a term of a 24-month bank loan, c) non-bank profit sharing is set at $20 \%$, d) term of a 12-month non-bank loan.

The conclusion that can be drawn from the simulation is that for both ship owners and crew, the best financing scheme is self-financing. If then external financing is needed, then the best financing scheme is financing from the bank. Financing schemes from loans to other ship owners are the worst schemes in the order of the existing schemes.

While for the most profitable net income sharing scheme for ship owners, it is divided into three parts, boat rental, shipowner, and crew. The scheme allows ship owners to obtain two parts of the net profit of the business from the rented boat part and the share of profits. On the other hand, the most profitable financing for the crews is the profit-sharing into two parts.

\section{Adaptive Financing Patterns of Banking Institution for Pajeko Fisheries}

Banking institutions need to understand the characteristics and behavior of pajeko fisheries to be able to offer financing products that are appropriate, applicable, and adaptive. The products offered at least meet the criteria for financing patterns that fit the needs and abilities of fishermen. The criteria based on five related factors are as follows: The facility of access and loan processes that pay attention to simple and easy loan procedures, a short and fast administrative process, and intensive and periodic communication; The flexibility of the installment mechanism that takes into account the adaptive and flexible installment, the installment according to the catch season, and the customer visit method; Collateral flexibility by expanding the range of collateral types, including boats, and reducing collateral value less than $100 \%$ of the total loan; Determination of loan interest that is adaptive to the conditions of the small-scale fisheries, so that during low season some of the interest can be paid in the peak season; The timing of the loan is designed to be more adaptive to the conditions of pajeko fisheries so that it allows fishermen to delay installment payments during the low season without diverting the burden of the installment payments during the fishing season.

\section{Managerial Implication}

This research can provide managerial implications to the marketing division of banking institutions to have greater authority in determining the requirements for applying for business loans, especially for pajeko fisheries. The marketing division at the banking institution also needs to increase the capacity of field staff in understanding the small-scale capture fisheries business. Finally, branch managers and marketing managers of banking institutions need to improve coordination and communication with the relevant authorities regarding capture fisheries in Bitung. Periodic meetings need to be scheduled.

\section{CONCLUSIONS AND RECOMMENDATIONS}

\section{Conclusions}

The choice of small-scale fisheries to sources of credit financing is influenced by factors of easy access to financing sources with simple and easy-to-understand procedures, the flexibility of types and value of collateral, interest rates and installment payments with the flexibility of the pattern and time of installment payments. Based on these factors, most fishermen prefer non-bank financing sources, especially from individual creditors. Pajeko fishermen see the flexibility of financing patterns from individual creditors to be more adaptive according to their needs and abilities. 


\section{Recommendations}

Based on the results of this study, banking institutions must prepare more adaptive financing patterns for the conditions of small-scale fisheries, especially pajeko fisheries in Bitung. The financing pattern must be easy to apply and flexible to be adjusted in certain seasons. Banking institutions must also be able to better understand the characteristics of pajeko fisheries in preparing appropriate, applicable, and adaptive financing patterns. Preparing fishery production data regularly will greatly help creditors understand the characteristics of the fishery.

\section{REFERENCES}

Abdesamed KH, Kalsom AW. 2014. Financing of small and medium enterprises (SMEs): determinants of bank loan application. Academic Journals of Business Management 8(17): 717-727. https:// doi.org/10.5897/AJBM2013.7222.

[BI] Bank Indonesia. 2016. Kelayakan usaha. https:// www.bi.go.id/id/umkm/kelayakan/polapembiayaan/default.aspx. [17 September 2018].

Destiana R. 2016. Analisis faktor-faktor internal yang mempengaruhi pembiayaan usaha mikro kecil dan menengah (UMKM) pada bank syariah di Indonesia. JRKA 2(1): 15-28. https://doi. org/10.25134/jrka.v2i1.444.

Fathanah Y. 2014. Analisis karakteristik Perikanan tangkap skala kecil di Kabupaten Pacitan, Jawa Timur [tesis]. Bogor: Sekolah Pascasarjana IPB.

Hajatuddin MT. 2008. Karakteristik upaya penangkapan mini purse seine (soma pajeko) di Kota Tidore Kepulauan [tesis]. Bogor: Sekolah Pascasarjana IPB.

Hidayat AS. 2009. Analisis kapasitas unit penangkap ikan skala kecil (kasus perikanan pelagis di Kabupaten Bangka) [tesis]. Bogor: Sekolah Pascasarjana IPB.

Ilhamdi H, Kuswoyo A. 2013. Pengamatan aspek operasional pukat cincin yang berbasis di PPN Prigi Jawa Timur. Jurnal BTL 11(1): 33-36.

Jasuni AY. 2018. Micro financing optimalization strategy for MSMEs development (case study at Kabupaten Bogor, Indonesia). Indonesian Journal of Business and Entrepreneurship 4(2):161. https://doi.org/10.17358/ijbe.4.2.161.

Karauwan F. 2012. Analisis kebijakan kredit usaha pada bank BRI kantor cabang pembantu Mega Mas
Manado. Journal “Acta Diurna” 1(1): 1-10.

Kusumawati P, Rosyid A, Kohar MA. 2010. Upaya peningkatan kinerja usaha Perikanan melalui peningkatan lingkungan usaha pada alat tangkap cantrang (Boat Seine) dan kebijakan pemerintah daerah di kabupaten Rembang. Jurnal Saintek Perikanan 6(1): 36-45.

Lewar MS, Abduh T, Jafar S. 2017. Analisis faktorfaktor yang mempengaruhi produksi nelayan ikan laut di Desa Nangahale Kecamatan Talibura Kabupaten Sikka Propinsi NTT. Jurnal Riset Bosowa 3(3): 24-37.

Masyhuri. 2014. Pembiayaan nonformal usaha perikanan tangkap: kasus Muncar dan Bitung. Jurnal Ekonomi dan Pembangunan 22(2): 135148.

Nababan DI, Hamorain HD. 2013. Analisis faktorfaktor yang memengaruhi keputusan masyarakat kecamatan Medan Helvetia dalam memilih Lembaga keuangan sebagai sumber pendanaan. Jurnal Ekonomi dan Keuangan 1(6): 17-24.

Noor R. 2018. Pemprov Sulut perkuat sektor perikanan. https://manado.tribunnews.com/2018/04/20/ pemprov-sulut-perkuat-sektor-perikanan [25 November 2019].

Nugrohadi IAN. 2013. Strategi dan kebijakan membangun daya saing perikanan Kabupaten Natuna [disertasi]. Bogor: Sekolah Pascasarjana IPB.

Nurlestari A, Mahfud MK. 2015. Analisis faktor-faktor yang mempengaruhi penyaluran kredit UMKM: studi pada bank umum yang terdaftar di Bursa Efek Indonesia periode 2009-2013. Diponegoro Journal of Management 4(4): 1-12. https://doi. org/10.21831/nominal.v4i1.6888.

Panekenan D, Rumagit GAJ, Pangemanan PA. 2017. Peran kredit perbankan pada sektor pertanian di Provinsi Sulawesi Utara. Jurnal AgriSosioEkonomi UNSRAT 13(1) :183-194. https:// doi.org/10.35791/agrsosek.13.1A.2017.15623.

Purba CB, Haluan J, Simbolan D, Wisudo SH. 2008. Model pengembangan kemitraan usaha perikanan tangkap dengan lembaga keuangan di Kabupaten Indramayu. Bulletin PSP 17(3): 297-305.

Respatiningsih H. 2011. Manajemen kredit usaha mikro kecil dan menengah (UMKM). Jurnal Manajemen dan Bisnis SEGMEN 15(2): 48-65.

Santoso I. 2010. Pengembangan model pemberdayaan ekonomi masyarakat petani tepian hutan berbasis perilaku adaptif: analisis sosio kultur. Jurnal Ekonomi 13(3): 92-98. 
Suci YR. 2017. Perkembangan UMKM (usaha mikro kecil dan menengah) di Indonesia. Jurnal Ilmiah Cano Ekonomos 6(1): 51-58.

Wijaya E, Kesumawardhani A. 2010. Analisis faktorfaktor yang mempengaruhi ourstanding kredit umum pedesaan (KUPEDES) PT Bank Rakyat Indonesia (Persero), TBK. Jurnal Media Ekonomi 18(1): 65-84. https://doi.org/10.25105/ me.v18i1.9.
Witomo. 2012. Potret Perikanan tangkap tuna, cakalang dan layang di kota Bitung. Buletin Riset Sosek Kelautan dan Perikanan 7(1): 8. https://doi. org/10.15578/marina.v7i1.4592.

Yuniarti S. 2010. Strategi adaptif Bank Perkreditan Rakyat dalam menghadapi ekspansi kredit UMKM bank umum di Malang. Jurnal Keuangan dan Perbankan 15(3): 437-445. 